\title{
Eurasian otter Lutra lutra in developing countries: a resurvey of Albania 22 years after the fall of communism
}

\author{
Alessandro Balestrieri, Simone Messina, Francesca Pella \\ Claudio Prigioni, Nicola Saino and Mauro Fasola
}

\begin{abstract}
In countries with emerging and developing economies the need to promote development and the lack of information on the status of the Near Threatened Eurasian otter Lutra lutra have given rise for concern about the conservation status of the species. In Albania information about the distribution of this otter dates from 1985. In 2013 we resurveyed 31 sites previously surveyed in 1985 , and a further 42 sites throughout the country. At each site nine habitat variables of potential importance to otters were recorded and analysed. Overall the distribution pattern in 2013 did not differ from that recorded in 1985 , although a reduction in marking intensity suggested a possible decline in otter numbers. Distribution of the otter has been influenced by land use and human density, suggesting man-induced habitat changes since the fall of communism may have affected the quality and fragmentation of otter habitats.
\end{abstract}

Keywords Albania, distribution, Eurasian otter, habitat change, Lutra lutra, monitoring, standard survey, transitional countries

This paper contains supplementary material that can be found online at http://journals.cambridge.org

\section{Introduction}

Collowing a dramatic decline in both range and popuClation in the second half of the 2oth century, the Eurasian otter Lutra lutra is recovering in several European countries, including the UK (Crawford, 2003), Sweden (Roos \& Rigét, 2011), Denmark (Elmeros et al., 2006), France (Janssens et al., 2006), Spain (Ruiz-Olmo \& Delibes, 1998) and Italy (Prigioni et al., 2007). This recovery is probably largely attributable to efforts in the 1970 s to ban

Alessandro Balestrieri (Corresponding author) and Nicola Saino Department of Biosciences, University of Milan, Via Celoria 26, 20133 Milan, Italy E-mail alebls@libero.it

Simone Messina Department of Biology and Biotechnology, Sapienza University, Rome, Italy

Francesca Pella IUCN, Rruga Abdi Toptani, Torre Drin, Tirana, Albania

Claudio Prigioni and Mauro Fasola Department of Earth and Environmental Sciences, University of Pavia, Pavia, Italy

Received 29 July 2014. Revision requested 18 September 2014.

Accepted 10 October 2014. First published online 11 February 2015. persistent organic pollutants, especially synthetic pesticides (lindane, DDT) and chlorinated biphenyls (Ruiz-Olmo et al., 2000).

Although most industrially developed countries have made progress in controlling pollution and implementing conservation measures, in transitional or developing economies biodiversity governance is hindered by ongoing institutional change and the need to promote economic development, which often result in overexploitation of natural resources (CEC, 2001; Kluvánková-Oravská et al., 2009). Approximately $60 \%$ of the countries within the Eurasian otter's range have been listed as emerging and developing economies by the International Monetary Fund (IMF, 2012), and the species' population trend in the eastern part of its range was the basis for its categorization as Near Threatened on the IUCN Red List in 2004 (Ruiz-Olmo et al., 2008).

Information about the current status of the species in many developing countries is scarce. Although the otter population is increasing in Poland (Romanowski, 2006) and may not have declined in Hungary during the second half of the 2oth century (Heltai et al., 2012), the species has reportedly declined in Turkey (Kayaöz, 2002; Özdemir, 2002), the South Caucasus region (Georgia, Armenia and Azerbaijan; Gorgadze, 2011), Belarus (Sidorovich, 2011), Nepal (Bhandari, 2011) and Morocco (Delibes et al., 2012).

In Albania the communist era ended in 1991. The transition from centralized management of land and natural resources to a market-oriented economy has caused widespread damage to the environment (Jansen et al., 2006), especially to aquatic ecosystems of the western lowlands, as a result of increased urbanization, overexploitation of woodland and ineffective waste management (Cullaj et al., 2005; Keukelaar et al., 2006).

Except for a few more recent surveys in the southern part of the country (rivers Seman and Drinos; Bego et al., 2011; Hysaj et al., 2013), information about the distribution of the otter in Albania dates back to 1985, when during 18-27 May Prigioni et al., surveyed 31 sites, mostly in the western lowlands and in the upper catchment of the River Shkumbin (Prigioni et al., 1986). The rationale for the survey method was based on Erlinge's recommendations; stretches of river up to $600 \mathrm{~m}$ long were surveyed for otter spraints and footprints on both banks (Chanin, 2003). A minimum 


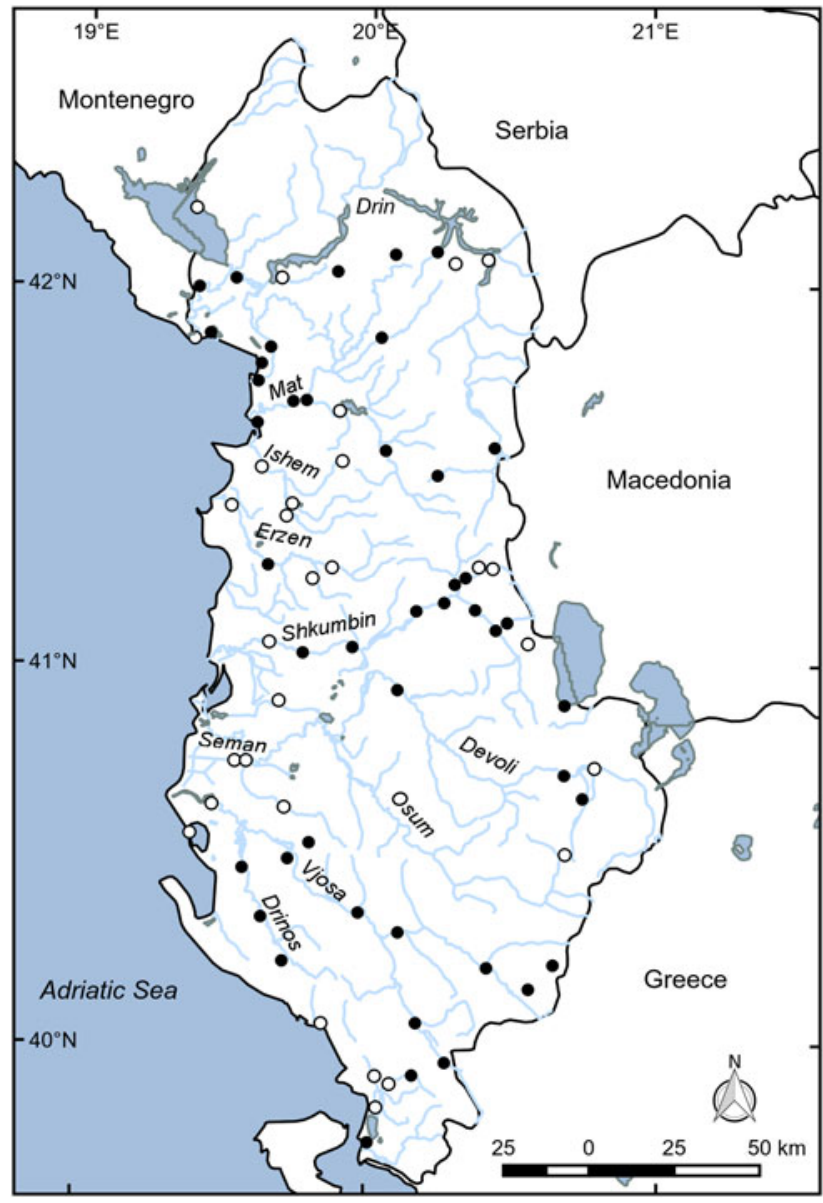

FIG. 1 Sites surveyed for the Eurasian otter Lutra lutra in Albania in 2013. Filled and unfilled circles indicate otter presence and absence, respectively.

distance of $200 \mathrm{~m}$ was surveyed per site and the otter was presumed absent if no sign was detected along the transect. To update information on the distribution of the Eurasian otter in Albania and to assess the impact of political and economic changes on the species' conservation by comparing current and past range, we resurveyed the major watercourses and coastal lagoons of Albania in summer 2013.

\section{Methods}

Following the same protocol used by Prigioni et al. (1986), during 24 June-18 July 2013 we resurveyed the 31 sites surveyed in 1985, and an additional 42 sites, thus surveying all the major river catchments of Albania (Fig. 1). We used a $1: 200,000$ road map to select sites, which were chosen for ease of access, mainly at road bridges, to maximize the probability of finding signs quickly (Chanin, 2003). Sites were separated by at least $5 \mathrm{~km}$. Twenty-nine sites were on main rivers, 26 on tributaries, seven on canals, five on lakes (Shkodrës, Ohrit, Vaut të Dejës, Fierzes) and six on coastal lagoons (Butrinti, Narta, Ceke, Merxhani, Patok, Viluni; Peja et al., 1996). Mean transect length was $587 \mathrm{~m}$ (range 380-1000 m). The most thoroughly surveyed catchments were those of the rivers Shkumbin $(n=13)$, Vjosa $(n=18)$, Mat $(n=6)$ and Ishëm-Erzen $(n=7)$; relative to their total length, few sites were located in the catchments of the rivers where otter occurrence had been confirmed recently. All sites were georeferenced using a global positioning system. To avoid bias as a result of variation in experience with sampling, all surveys were carried out by the same trained staff.

Sprainting sites were identified as places with spraints separated by at least $1 \mathrm{~m}$ from other spraints (Kruuk et al., 1986). Following Prigioni et al. (1986) an index of otter marking intensity was calculated as the number of sprainting sites or spraints per $200 \mathrm{~m}$. We assumed marking intensity represented a broad index of relative abundance (Mason \& Macdonald, 2004). The percentage of sites where otters were present in 1985 was compared to that found in 2013 ( $\chi^{2}$ test), with respect to both the total number of sites $(n=73)$ and the number of sites surveyed in both years $(n=31)$. For the latter sample the distribution of sites with presence and absence was compared using a $2 \times 2$ summary table of coincidences and discrepancies.

For each site on a watercourse five habitat variables of potential importance to otters (Prenda et al., 2001; Remonti et al., 2008) were recorded visually in the field (Supplementary Table S1). Watercourse width and depth were estimated at intervals of c. $200 \mathrm{~m}$ and the mean values for each site were assigned to one of four classes $(\leq 2.0,2.1-$ $6.0,6.1-15.0$ or $>15.0 \mathrm{~m}$, and $\leq 0.5,0.51-1.0,1.1-2.0$ or $>2.0 \mathrm{~m}$, respectively). Water speed was categorized as stagnant, slow or moderate-high. The dominant land use within a $100 \mathrm{~m}$ wide belt on both river banks was estimated and categorized as bare soil, crops, pasture/shrubs or woods. Water pollution was categorized as absent (transparent water in $\geq 70 \%$ of watercourse depth, without any sign of pollution), low (less transparent water, solid waste on the banks), medium-high (clear signs of pollution, such as bad smell, turbidity, foam). Mean altitude was recorded for each site ( $\leq 250,251-500,501-750,>750 \mathrm{~m})$. To assess the influence of human disturbance on otter occurrence, using GE-Path v. 1.4.6 (Sgrillo, Ilhéus, Brazil), we assessed the overall percentage cover of agricultural and urban areas in a $4 \mathrm{~km}^{2}$ area centred on each site, by superimposing a $200 \times 200 \mathrm{~m}$ grid on satellite images provided by Google Earth (Google, Mountain View, USA). Results were categorized as $\leq 25,25.1-50,50.1-75$ or $>75 \%$.

Otter presence/absence was then modelled against the predictor variables by backward stepwise logistic regression, using Wald's test to examine the statistical significance of each coefficient in the model. To avoid collinearity, which can inflate the standard errors of the estimates of model coefficients and produce unreliable results (Hosmer \& 
Lemeshow, 1989), the correlation between the predictors was measured by Spearman's coefficient. Model variables were then selected, omitting those that represented redundant information; when two variables were correlated $(\mathrm{P}<0.01)$, the one to be rejected was chosen according to the strength of its correlation with the dependent variable. Analyses were performed only for sites on watercourses, as most habitat variables could not be assessed precisely for lakes and lagoons.

Finally, from the last human population census (INSTAT, 2011) we obtained the population density (inhabitants per $\mathrm{km}^{2}$ ) of the counties ( qarku; $\mathrm{n}=12$ ) and municipalities where sampling sites were located. For sites in the same administrative area the results were pooled to avoid pseudoreplication (Hurlbert, 1984), and mean values for positive and negative sites were compared using the Mann-Whitney test. The relationship between marking intensity and either altitude or population density was examined using Spearman's correlation test.

\section{Results}

Otter signs were detected at $44(60.3 \%)$ of the 73 survey sites. From north to south, the species was widespread in the catchments of the rivers Drin, Mat, Shkumbin and Seman (where the otter occurred in the plain of Coriza) and absent on the rivers Gjanica and Vjosa. Otter signs were not found in the downstream stretches of the rivers Shkumbin, Seman and Vjosa, which cross the intensively populated plain facing the Adriatic Sea. No otter sign was found in the catchments of the rivers Ishëm (which runs through the counties of Durazzo) or Tirana and Bistrice, in the south, whereas otter presence was detected at one of four sites in the catchment of the River Erzen (Fig. 1). Otters were present in five of six lagoons and in the Lake of Ocrida (Ohrit), and absent from the Lake of Scutari (Shkodrës) and two of three artificial lakes (Liqueni Fierzes and Liqeni i Vaut të Dejës).

The percentage of surveyed sites where otters were present did not differ from that recorded in the 1985 survey ( 60.3 vs $54.8 \% ; \chi^{2}=0.27, P=0.61$ ), even considering only the sites surveyed in both years (61.4 vs $54.8 \% ; \chi^{2}=0.26$, $\mathrm{P}=0.61$ ). The distribution of presence and absence was also similar: otter status in 2013 was the same as in 1985 for $71 \%$ of sites $\left(\chi^{2}=10.9, \mathrm{P}=0.001\right)$. In contrast, marking intensity was lower in 2013 than in 1985 (Table 1).

Logistic regression identified percentage cover as the main variable affecting the occurrence of the otter (Table 2). Pecentage cover was negatively correlated with mean altitude $(\rho=-0.42, P=0.0006, n=62)$ and positively correlated with water pollution $(\rho=0.44, P=0.0003$, $\mathrm{n}=62$ ).

Marking intensity was not correlated with any of the variables tested. Mean human population density of
TABLE 1 Otter Lutra lutra mean marking intensity along seven major rivers in Albania (Fig. 1), and at all sites surveyed for otters in 1985 (Prigioni et al., 1986) and 2013 (blank cells indicate unsurveyed sites).

\begin{tabular}{|c|c|c|c|c|}
\hline \multirow[b]{2}{*}{ River } & \multicolumn{2}{|l|}{1985} & \multicolumn{2}{|l|}{2013} \\
\hline & $\begin{array}{l}\text { Sites per } \\
200 \mathrm{~m}\end{array}$ & $\begin{array}{l}\text { Spraints per } \\
200 \mathrm{~m}\end{array}$ & $\begin{array}{l}\text { Sites per } \\
200 \mathrm{~m}\end{array}$ & $\begin{array}{l}\text { Spraints per } \\
200 \mathrm{~m}\end{array}$ \\
\hline Drin/Buna & 0.8 & 0.8 & 0.4 & 0.4 \\
\hline Mat & 3.6 & 5.8 & 1.0 & 1.4 \\
\hline Shkumbini & 0.7 & 2.6 & 0.8 & 1.1 \\
\hline $\begin{array}{l}\text { Devoll/ } \\
\text { Dunacecit }\end{array}$ & & & 0.7 & 2.6 \\
\hline Vjosa & & & 0.7 & 2.6 \\
\hline Shushice & & & 0.9 & 1.1 \\
\hline Bistrice & 3.3 & 7.3 & & \\
\hline $\begin{array}{l}\text { All surveyed } \\
\text { sites }\end{array}$ & 1.7 & 3.6 & 0.78 & 1.1 \\
\hline
\end{tabular}

municipalities was significantly lower for sites where otters were present than sites where they were absent ( 62.3 vs 250.5 inhabitants per $\mathrm{km}^{2} ; \mathrm{U}=311, \mathrm{P}=0.028$ ).

\section{Discussion}

The distribution of the otter in Albania in 2013 was similar to that recorded by Prigioni et al. (1986) in 1985. Otters were absent on the coastal stretches of the rivers Gjanica, Seman and Vjosa, where oil extraction and refinement remain the primary source of water pollution (Cullaj et al., 2005), whereas urban and industrial waste, together with increased urbanization, probably prevent colonization of the catchments of the rivers Ishëm and Erzen. The largest difference was recorded in the River Bistrice, the river with the highest marking intensity in 1985, where otters are now absent from two of three sites where they were present in 1985. In a report by the Government of Albania, direct killing has been indicated as the main threat to otters in the Southern Coastal Plain, but the River Bistrice has been canalized for much of its length and the whole watershed area has been degraded by uncontrolled urbanization (PAP/RACSOGREAH, 2005), suggesting that habitat alteration may have been a significant factor in the decline of the otter.

Although no habitat variable seemed to affect distribution at a local scale, confirming that otters are tolerant of a wide range of habitat conditions (Chanin, 2003), at the landscape scale the effect of land use and human population density may be regarded as an index of the impact of human activities on otter occurrence. Similarly, on the Iberian Peninsula otter distribution was reported to be affected by human variables such as distance to major urban centres and to highways, which were related to water pollution downstream (Barbosa et al., 2003). 
TABLE 2 Results of backward stepwise logistic regression with otter presence/absence as the dependent variable and five habitat variables of potential importance to otters as independent variables.

\begin{tabular}{|c|c|c|c|c|c|}
\hline Variables & $\mathrm{B}^{2}$ & Wald statistic & df & $\mathrm{P}$ & $\operatorname{Exp}(B)^{3}$ \\
\hline$\%$ cover $^{1}$ & $0.021 \pm$ SE 0.008 & 7.207 & 1 & 0.007 & 1.022 \\
\hline Constant & $-1.487 \pm$ SE 0.508 & 8.564 & 1 & 0.003 & 0.226 \\
\hline
\end{tabular}

${ }^{1} \%$ cover of agricultural and urban areas in a $4 \mathrm{~km}^{2}$ area centred on each survey site

${ }^{2}$ Logistic coefficient

${ }^{3}$ Odd ratios

Although there is no direct relationship between numbers of spraints and numbers of otters, sprainting activity reflects changes in the distribution of otters (Chanin, 2003) and increases with otter numbers (Lanszki et al., 2008) and habitat use (Clavero et al., 2006). In general, 200-600 m surveys are effective for ascertaining otter presence (Chanin, 2003); to assess marking intensity, however, constant-length surveys are recommended (Balestrieri et al., 2011). Nonetheless, the numbers of spraints and sprainting sites did not differ from those recorded in surveying a $60 \mathrm{~km}$ stretch of the River Drinos (Hysaj et al., 2013), and corresponded to those reported for peripheral areas of the otter's range in Italy (Prigioni et al., 2006; Balestrieri et al., 2008). Although two surveys are insufficient to assess any trend in the otter population in Albania, variation in marking intensity suggests that changes in socio-economic policies during 1986-2013 may have had a greater impact on otter numbers than on the large-scale distribution of the species.

During the early transitional period from communism to democracy, lack of control and effective management policies exacerbated the environmental problems inherited from the previous centralized planning political model. Privatization of land has led to the urbanization of plains and the conversion of land-use from broadleaved forests to herbaceous crops in hilly areas, with detrimental effects on the environment (Jansen et al., 2006). Uncontrolled fishing, deforestation, river-bed excavation and pollution of rivers by wastewater from tanneries and petroleum refineries are still considered major threats to the otter (Cullaj et al., 2005; Hysaj et al., 2013). The burning of urban waste in the open air is the main contributor of PCDD/PCDF (polychlorinated dibenzo-p-dioxin and dibenzofuran) emissions into freshwater (Kleger et al., 2006).

Nonetheless, since the beginning of the 21st century there has been increased awareness of environmental problems, and some progress has been made in policy and legislation. A National Strategy and Action Plan for Biodiversity was approved in 2000, and in 2007 the otter was included in the Red Data Book of Albanian fauna, categorized as Vulnerable (Cullaj et al., 2005; Hysaj et al., 2013), although it can still be hunted under permit, to prevent damage to fisheries. The Stockholm Convention was signed in 2001 and a National Implementation Plan for the reduction and disposal of persistent organic pollutants was approved in 2006.
The otter is still widespread in Albania, and effective pollution management policies may favour the reinforcement of otter populations in the future, as has occurred in several European countries (Ruiz-Olmo et al., 2000). As shown by the systematic monitoring of otter populations in the UK (e.g. Strachan, 2007), annual otter surveys, complemented by effective statistical analysis of pollution data collected by environment protection agencies, can identify habitat changes and guide conservation programmes.

\section{Acknowledgements}

This study was conducted within the framework of the Institutional Support to the Albanian Ministry of Environment, Forest and Water Administration (MoEFWA) for Sustainable Biodiversity Conservation and Use in Protected Areas project by IUCN, funded by the Italian Ministry of Foreign Affairs, General Directorate for Cooperation Development, in collaboration with MoEFWA. We thank the project manager, Andrea Ghiurghi, for supporting and facilitating the research, and the trainees of the Animal Ecology Units of IUCN's project, specifically Tonin Macaj, Eduard Gajtani, Zeqir Ujka, Festim Broja and Elvin Shala (APA Shkoder) of the Buna River Protected Landscape, and Lavdim Qoshi, Enver Koçi, Mitat Bicaku (Librazhd Forest Office), Eriola Katjai, Luljeta Koçi and Bledar Pepa (Elbasan University), and Bledi Oxha (PPNEA NGO) of Shebenik-Jabllanice National Park. We thank Etleva Hysaj and Ferdinand Bego for help with fish identification and promoting research on otters in Albania. Lesley C. Wright (IUCN Species Survival Commission Otter Specialist Group) and Prof. Christopher F. Mason kindly revised the English.

\section{References}

Balestrieri, A., Remonti, L. \& Prigioni, C. (2011) Detectability of the Eurasian otter by standard surveys: an approach using marking intensity to estimate false negative rates. Naturwissenschaften, 98, 23-31.

Balestrieri, A., Remonti, L., Smiroldo, G., Prigioni, C. \& RegGiani, G. (2008) Surveying otter Lutra lutra distribution at the southern limit of its Italian range. Hystrix, The Italian Journal of Mammalogy, 19, 165-173. 
Barbosa, A.M., Real, R., Olivero, J. \& Vargas, J.M. (2003) Otter (Lutra lutra) distribution modeling at two resolution scales suited to conservation planning in the Iberian Peninsula. Biological Conservation, 114, 377-387.

Bego, F., Malltezi, J., Beqiraj, S. \& Xhulaj, S. (2011) On the presence, conservation status and distribution of the otter (Lutra lutra) in the Semani river watershed. International Journal of Ecosystems and Ecology Science, 1, 43-49.

Bhandari, J. (2011) Distribution and major threats to otter on River Karnali, Bardia National Park, Nepal. In XIth International Otter Colloquium (eds C. Prigioni, A. Loy, A. Balestrieri \& L. Remonti). Hystrix, The Italian Journal of Mammalogy, Supp (2011), 75.

CEC (Commission of the European Communities) (2001) Biodiversity Action Plan for Economic and Development Co-operation. Communication from the Commission to the Council and the European Parliament, 27 March 2001.

Chanin, P. (2003) Monitoring the Otter Lutra lutra. Conserving Natura 2000 Rivers: Monitoring Series No. 10, English Nature, Peterborough, UK.

Clavero, M., Prenda, J. \& Delibes, M. (2006) Seasonal use of coastal resources by otters: comparing sandy and rocky stretches. Estuarine, Coastal and Shelf Science, 66, 387-394.

Crawford, A. (2003) Fourth Otter Survey of England 2000-2002. Environment Agency, Bristol, UK.

Cullaj, A., Hasko, A., Miho, A., Schanz, F., Brandl, H. \& BACHOfEn, R. (2005) The quality of Albanian natural waters and the human impact. Environment International, 31, 133-146.

Delibes, M., Calzada, J., Clavero, M., Fernández, N., Gutiérrez-Expósito, C., Revilla, E. \& Román, J. (2012) The Near Threatened Eurasian otter Lutra lutra in Morocco: no sign of recovery. Oryx, 46, 249-252.

Elmeros, M., Hammershøj, M., Madsen, A.B. \& Søgaard, B. (2006) Recovery of the otter Lutra lutra in Denmark monitored by field surveys and collection of carcasses. Hystrix, The Italian Journal of Mammalogy, 17, 17-28.

Gorgadze, G. (2011) Current status and threats affecting otter (Lutra lutra) population in the South Caucasus. In XIth International Otter Colloquium (eds C. Prigioni, A. Loy, A. Balestrieri \& L. Remonti). Hystrix, The Italian Journal of Mammalogy, Supp (2011), 74

Heltai, M., Bauer-Ház, É.A., Lehoczki, R. \& LansZKi, J. (2012) Changes in the occurrence and population trend of the Eurasian otter (Lutra lutra) in Hungary between 1990 and 2006. North-Western Journal of Zoology, 8, 112-118.

Hosmer, D.W. \& Lemeshow, S. (1989) Applied Logistic Regression. Wiley, New York, USA.

Hurlbert, S.H. (1984) Pseudoreplication and the design of ecological field experiments. Ecological Monographs, 54, 187-211.

Hysaj, E., Bego, F., Prigioni, C. \& Balestrieri, A. (2013) Distribution and marking intensity of the Eurasian otter, Lutra lutra, on the River Drinos (southern Albania). Folia Zoologica, 62, 115-120.

imf (International Monetary Fund) (2012) World Economic Outlook, April 2012: Growth Resuming, Dangers Remain. IMF, Washington, DC, USA.

INSTAT (Instituti i Statistikës Republika e Shqipërisë) (2011) Population and Housing Census 2011. INSTAT, Tirana, Albania.

Jansen, L.J.M., Carrai, G., Morandini, L., Cerutti, P.O. \& Spisni, A. (2006) Analysis of the spatio-temporal and semantic aspects of land-cover/use change dynamics 1991-2001 in Albania at national and district levels. Environmental Monitoring and Assessment, 119, $107-136$.
Janssens, X., Defourny, P., De Kermabon, J. \& Baret, P.V. (2006) The recovery of the otter in the Cevennes (France): a GIS-based model. Hystrix, The Italian Journal of Mammalogy, 17, 5-14.

KAYAÖZ, E. (2002) Türkiye'deki Su Samuru (Lutra lutra)'nun Korumasının Önemi ve Yasama Alanların Saptam Çalısmalar. In Proceedings of the Second Symposium on the Situation of the Fischotter in Turkey, Antalya, September 2002, pp. 31-38. TTKD \& Tübitak, Ankara, Turkey.

Keukelaar, F., De Goffau, A., Pradhan, T., Sutmuller, G., Misurovic, A., Ivanovic, S. et al. (2006) Lake Shkoder Transboundary Diagnostics Analysis: Albania and MontenegroFinal Report. World Bank, Washington, DC, USA.

Kleger, L., Kuncová, H., Mansaku-Meksi, M., Selfo, L. \& Baraj, B. (2006) Country Situation Report on POPs in Albania. Arnika, Prague, Czech Republic, and EDEN Centre, Tirana, Albania.

Kluvánková-Oravská, T., Chobotová, V., Banaszak, I., Slavikova, L. \& Trifunovova, S. (2009) From government to governance for biodiversity: the perspective of central and Eastern European transition countries. Environmental Policy and Governance, 19, 186-196.

Kruuk, H., Conroy, J.W.H., Glimmerveen, U., Ouwerkerk, E.J. (1986) The use of spraints to survey populations of otters Lutra lutra. Biological Conservation, 35, 187-194.

Lanszki, J., Hidas, A., Szentes, K., Révay, T., Lehoczky, I. \& Weiss, S. (2008) Relative spraint density and genetic structure of otter (Lutra lutra) along the Drava River in Hungary. Mammalian Biology, 73, 40-47.

Mason, C.F. \& Macdonald, S.M. (2004) Growth in otter (Lutra lutra) populations in the UK as shown by long-term monitoring. Ambio, 33, 148-152.

Özdemir, N. (2002) Muğla Đlindeki Mevcut Alabalık Đsletmelerinde Su Samurları Konusunda Yapılan Bilinçlendirme ve Eğitim Calismalar. In Proceedings of the Second Symposium on the Situation of the Fischotter in Turkey, Antalya, September 2002, pp. 15-20. TTKD \& Tübitak, Ankara, Turkey.

PAP/RAC-SOGREAH (2005) Integrated Coastal Development Study and Plan: Interim Report. Goverment of Albania, Tirana, Albania.

Peja, N., Vaso, A., Miho, A., Rakaj, N. \& Crivelli, A.J. (1996) Characteristics of Albanian lagoons and their fisheries. Fisheries Research, 27, 215-225.

Prenda, J., López-Nieves, P. \& Bravo, R. (2001) Conservation of otter (Lutra lutra) in a Mediterranean area: the importance of habitat quality and temporal variation in water availability. Aquatic Conservation: Marine and Freshwater Ecosystems, 11, 343-355.

Prigioni, C., Balestrieri, A. \& Remonti, L. (2007) Decline and recovery in otter Lutra lutra populations in Italy. Mammal Review, $37,71-79$.

Prigioni, C., Balestrieri, A., Remonti, L., Sgrosso, S. \& Priore, G. (2006) How many otters are there in Italy? Hystrix, The Italian Journal of Mammalogy, 17, 29-36.

Prigioni, C., Bogliani, G. \& Barbieri, F. (1986) The otter Lutra lutra in Albania. Biological Conservation, 36, 375-383.

Remonti, L., Prigioni, C., Balestrieri, A., Sgrosso, S. \& Priore, G. (2008) Distribution of a recolonising species may not reflect habitat suitability alone: the case of the Eurasian otter (Lutra lutra) in southern Italy. Wildlife Research, 35, 798-805.

Romanowski, J. (2006) Monitoring of the otter recolonisation of Poland. Hystrix, The Italian Journal of Mammalogy, 17, 37-46.

Roos, A. \& Rigét, F. (2011) Otters (Lutra lutra) in Sweden: body condition, reproduction and population between 1970 and 2010. In XIth International Otter Colloquium (eds C. Prigioni, A. Loy, 
A. Balestrieri \& L. Remonti). Hystrix, The Italian Journal of Mammalogy, Supp (2011), 76.

Ruiz-Olmo, J. \& Delibes, M. (1998) La nutria en España ante el horizonte del año 200o. SECEM, Málaga, Spain.

Ruiz-Olmo, J., Lafontaine, L., Prigioni, C., López-Martín, J.M. \& Santos-Reis, M. (200o) Pollution and its effects on otter populations in south-western Europe. In Proceedings of the First Otter Toxicology Conference (eds J.W.H. Conroy, P. Yoxon \& A.C. Gutleb), pp. 63-82. International Otter Survival Fund, Isle of Skye, Scotland.

Ruiz-Olmo, J., Loy, A., Cianfrani, C., Yoxon, P., Yoxon, G., DE Silva, P.K. et al. (2008) Lutra lutra. In IUCN Red List of Threatened Species. Http://www.iucnredlist.org [accessed 22 April 2014].

Sidorovich, V. (2011) Recent strong decline in otters Lutra lutra in Belarus: the data gained and hypothesis established. In XIth International Otter Colloquium (eds C. Prigioni, A. Loy, A. Balestrieri \& L. Remonti). Hystrix, The Italian Journal of Mammalogy, Supp (2011), 24.
Strachan, R. (2007) National Survey of Otter Lutra lutra Distribution in Scotland 2003-04. Scottish Natural Heritage Commissioned Report No. 211 (ROAME No. Fo3AC309). SNH, Inverness, Scotland.

\section{Biographical sketches}

Alessandro Balestrieri and Claudio Prigioni's research activities focus mainly on the behavioural ecology and conservation of meso-carnivores. They are also involved in the management of invasive coypus in northern Italy. Sim ONE Messina participated in this research for his undergraduate thesis. Francesca Pella is involved in conservation research, wildlife management, and capacity building in developing countries. NiCOLA SAINO's main research interests are sexual selection, the evolution and consequences of maternal effects, parent-offspring communication and sex allocation, and the impacts of climate change on migration phenology and population dynamics. MAURO FASOLA's research interests range from demography and foraging ecology of birds, to behaviour of reptiles, environmental contamination, and phylogeography. 